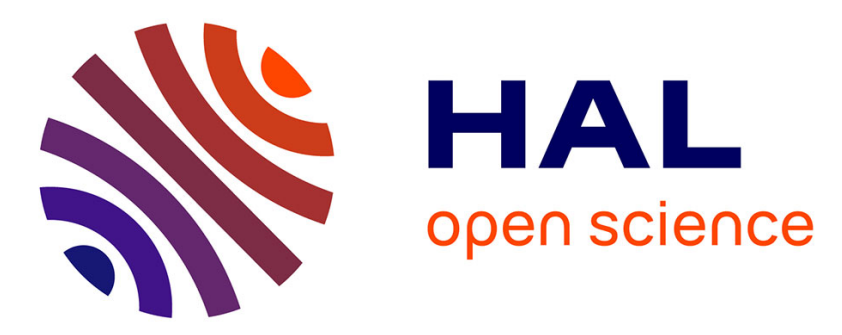

\title{
The rôle of plasma oxide in InP MIS structures
}

\author{
R. Carmona, J. Farré, D. Lecrosnier, F. Richou, J.J. Simonne
}

\section{To cite this version:}

R. Carmona, J. Farré, D. Lecrosnier, F. Richou, J.J. Simonne. The rôle of plasma oxide in InP MIS structures. Revue de Physique Appliquée, 1984, 19 (2), pp.155-159. 10.1051/rphysap:01984001902015500 . jpa-00245169

\section{HAL Id: jpa-00245169 https://hal.science/jpa-00245169}

Submitted on 1 Jan 1984

HAL is a multi-disciplinary open access archive for the deposit and dissemination of scientific research documents, whether they are published or not. The documents may come from teaching and research institutions in France or abroad, or from public or private research centers.
L'archive ouverte pluridisciplinaire HAL, est destinée au dépôt et à la diffusion de documents scientifiques de niveau recherche, publiés ou non, émanant des établissements d'enseignement et de recherche français ou étrangers, des laboratoires publics ou privés. 
Classification

Physics Abstracts

$73.40 \mathrm{Q}$

\title{
The rôle of plasma oxide in InP MIS structures $\left(^{+}\right)$
}

\author{
R. Carmona $(*)$, J. Farré $(*)$, D. Lecrosnier $\left({ }^{* *}\right)$, F. Richou $\left({ }^{* *}\right)$ and J. J. Simonne $\left({ }^{*}\right)$ \\ (*) Laboratoire d'Automatique et d'Analyse des Systèmes du C.N.R.S., \\ 7, Avenue du Colonel Roche, 31400 Toulouse, France \\ ${ }^{(* *)}$ Centre National d'Etudes des Télécommunications, Route de Trégastel, 22301 Lannion, France
}

(Reçu le 25 juillet 1983, révisé le 17 octobre, accepté le 21 octobre 1983)

\begin{abstract}
Résumé. - Un dépôt de silice obtenu par réaction à $250^{\circ} \mathrm{C}$ entre silane et oxyde nitreux est réalisé par CVD assisté par plasma sur un substrat InP, soit directement, soit après croissance d'un oxyde natif plasma à la surface $(\leqslant 100 \AA)$. On montre alors l'influence prépondérante de cette couche d'oxyde sur la qualité diélectrique de la structure MIS. Les résultats obtenus sur le plan de la qualité d'interface sur des structures non recuites, font apparaître une densité moyenne d'états rapides de $10^{12} \mathrm{~cm}^{-2} \mathrm{eV}^{-1}$ à l'interface InP/oxyde plasma, et la présence d'états lents situés essentiellement à la transition oxyde plasma $/ \mathrm{SiO}_{2}$. Une amélioration de ces propriétés passe par une optimisation de la température de réaction, des conditions de recuit, et de la composition des gaz réactants utilisés.
\end{abstract}

\begin{abstract}
Silicon dioxide formed by a plasma assisted reaction at $250^{\circ} \mathrm{C}$ between silane and nitrous oxide, has been deposited either directly or on a plasma oxide layer grown formely on the InP substrate, to realize a MIS structure. The quality of the plasma oxide layer $(\leqslant 100 \AA)$ is demonstrated through its effect on the rigidity of the MIS structure. Interface state densities on unannealed structures which include plasma oxide, is $10^{12} \mathrm{~cm}^{-2} \mathrm{eV}^{-1}$. Furthermore, the slow states located at the $\mathrm{SiO}_{2} /$ plasma oxide interface are minimized when the transition between the two oxides is abrupt. Factors of improvement are finally presented : annealing procedure, reaction temperature, composition of reacting gases.
\end{abstract}

\section{Introduction.}

The Plasma Enhanced Chemical Vapour Deposition (PECVD) process is - among a wide number [1] an attractive technique for insulator deposition on III-V compound semiconductors and, in recent years, has been widely used for MIS technology [2-5]. The physical reason of this interest is that a part of the thermal energy required to achieve the reaction in conventional CVD processes, is substituted by electron kinetic energy originating from the plasma. This procedure avoids excessive heating and subsequent degradation of the substrate which is generally observed at temperatures higher than $350^{\circ} \mathrm{C}$.

Insulating films used in the fabrication of devices on InP through this technique were formally limited to a $\mathrm{SiO}_{2}-, \mathrm{Si}_{3} \mathrm{~N}_{4}$ - or $\mathrm{Al}_{2} \mathrm{O}_{3}$ - layer deposition. Excellent dielectric quality of these films were normally encountered; however a current drift was systematically (and is still) observed on the characteristics of the corresponding MISFET. The origin of this

$\left(^{+}\right)$Work supported by DALI-CNET Contract. instability was attributed to the imperfection of the deposited insulator/InP interface and the possible interest of the presence of a thin layer of native oxide in between, to improve the surface characteristics of the substrate, was considered $[6,7]$.

Among the native oxides, the plasma oxide which can be readily grown prior to the insulator deposition in the same chamber, in fairly clean and reproducible conditions, appears as an attractive choice; this paper examines the impact of the plasma oxide on structures processed on $\mathrm{N}$-type, unintentionally doped InP material, with PECVD $\mathrm{SiO}_{2}$ used as active dielectric.

\section{Experimental procedure.}

2.1 Device Preparation. - All devices used in this investigation are issued from the same starting material. The surfaces were chemomechanically polished with a $1 \%$ bromine-methanol solution followed by sequential rinses in methanol, then rinsed in de-ionized (D.I.) water and blown dry with nitrogen. The silices are submitted to one out of four different cleaning procedures. 
- One, leaving a $20 \AA$ In-rich chemical native oxide at the surface : a $20 \mathrm{~min}$ bath in $\mathrm{NH}_{4} \mathrm{OH}$ / $\mathrm{H}_{2} \mathrm{O}_{2} / \mathrm{H}_{2} \mathrm{O}(5,1,100)$ at $80{ }^{\circ} \mathrm{C}$ (procedure $\mathrm{A}$ or $\mathrm{E}$ ) [8].

- The second, giving an oxide free surface by etching off the In-rich native oxide : the $20 \mathrm{~min}$ bath in $\mathrm{NH}_{4} \mathrm{OH} / \mathrm{H}_{2} \mathrm{O}_{2} / \mathrm{H}_{2} \mathrm{O}$ is followed by a $20 \mathrm{~min}$ bath in $\mathrm{ClH} / \mathrm{H}_{2} \mathrm{O}_{2} / \mathrm{H}_{2} \mathrm{O}(10,5,100)$ still at $80^{\circ} \mathrm{C}$ (procedure B or F) [9].

- The third giving also an oxide free surface, by using a 3 min etch 'in a $\mathrm{SO}_{4} \mathrm{H}_{2} / \mathrm{H}_{2} \mathrm{O}_{2} / \mathrm{H}_{2} \mathrm{O}(15,40,45)$ solution at room temperature, followed by rinses in D.I. water, methanol, isopropanol and acetone; then, just prior to introduction into the chamber, the slice is dipped into HF $49 \%$ during $30 \mathrm{~s}$ and dried in boiling acetone (procedure $\mathrm{C}$ or $\mathrm{G}$ [10]). The expression oxide free surface here, is used to emphasize the difference between a surface deliberately or non intentionally oxidized. By the way, the right procedure - which could not be used with our equipment - to get a real oxide free surface should have been to realize a $\mathrm{HCl}$ in situ etching just prior the insulator growth or deposition, as done by Fritzsche in this experiments [11].

- In the fourth procedure, the slice is used " as it is ", just dipped into HF to avoid any contamination in the reactor (procedure $\mathrm{D}$ or $\mathrm{H}$ ).

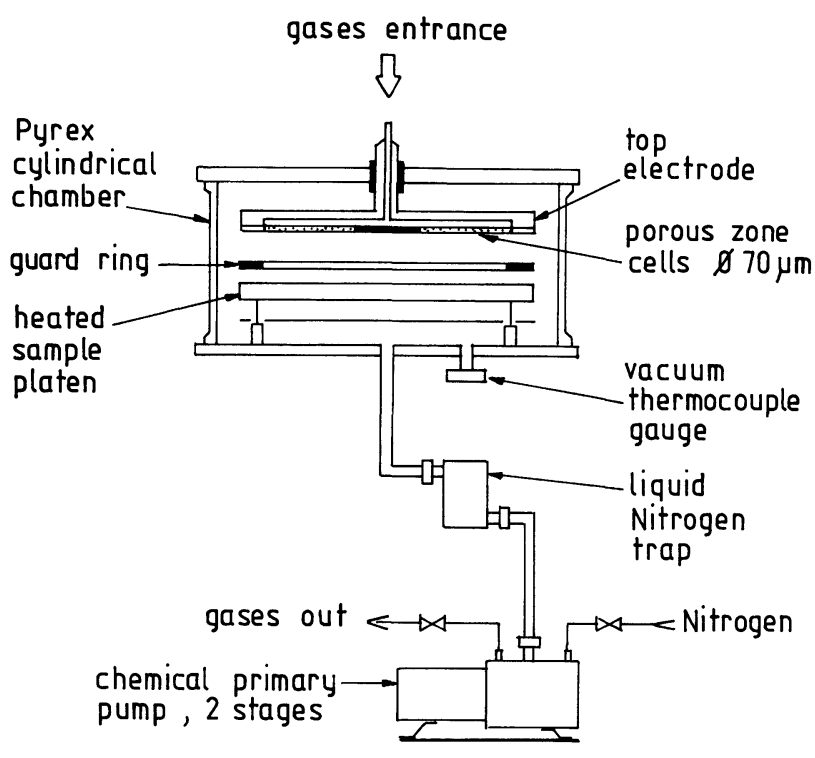

Fig. 1. - Schematical PECVD reactor cross-section.
The slices are rinsed in D.I. water and blown dry with nitrogen just prior to introduction into the chamber.

2.2 SYSTEM DESCRIPTION. - The reactor, whose configuration is shown schematically in figure 1 , is a SAPHYMO-STEL PSL 300 D type plasma reactor with a cylindrical pyrex chamber connected to a primary vacuum pump. The internal pressure during the reaction is $2 \times 10^{-1}$ torr, measured with a Baratron gauge. The ionization chamber is capacitively coupled to a $50 \mathrm{kHz}$ power supply generator. The power is $160 \mathrm{~W}$. The top plate is the high voltage circular electrode $(\varnothing: 35 \mathrm{~cm})$. The temperature is delivered by a resistance heater coil embedded in the platen, which is the grounded electrode. The substrates are heated at $250^{\circ} \mathrm{C}$ in these experiments. A guard ring, positively biased at $55 \mathrm{~V}$ is used to confine the plasma and to insure the uniformity of the deposition. Each gas line is controlled independently with a mass flowmeter; the introduction of gases into the chamber is provided in the top plate through a porous inox disc.

2.3 Technology. - The initial slice is cut into eight parts. Four of them, cleaned according to the procedure $\mathrm{A}$ to $\mathrm{D}$ are loaded into the clean chamber on the grounded plate. When a vacuum of $10^{-3}$ torr is reached and the temperature stabilized at $250^{\circ} \mathrm{C}$, $\mathrm{N}_{2}$ is introduced during $5 \mathrm{~min}$ for a purge of the system and for reducing the water vapour content of the residual atmosphere. Then, the $\mathrm{N}_{2} \mathrm{O}$ flow is established for the plasma oxide growth during $30 \mathrm{~min}$. A limited thickness of oxide, identified as $\mathrm{InPO}_{4}$ by some authors [12] [13] is obtained at the InP surface (probably lower than $100 \AA$ ). Then, $\mathrm{SiH}_{4}$ is introduced and can react with $\mathrm{N}_{2} \mathrm{O}$ to form $\mathrm{SiO}_{2}$. Nitrous oxide has been preferred over oxygen to avoid the silica dust which is often observed when a $\mathrm{SiH}_{4} / \mathrm{O}_{2}$ mixture is used. $\mathrm{A} \mathrm{SiO}_{2}$ thickness of $900 \AA$ to $1000 \AA$ is obtained after a 15 min reaction. Finally, $N_{2}$ is introduced into the chamber for $30 \mathrm{~min}$ without plasma to stabilize the insulator layer.

The other four parts of the slice, cleaned with the same procedures and classified $\mathrm{E}$ to $\mathrm{H}$, are submitted to the same cycle, except the plasma oxide.

The $\mathrm{N}_{2} \mathrm{O} / \mathrm{SiH}_{4}$ ratio (where $\mathrm{SiH}_{4}$ is $5 \%$ diluted in $\mathrm{N}_{2}$ ) has been fixed to $120 / 1.5$.

The overall procedure is summarized in the following sketch :

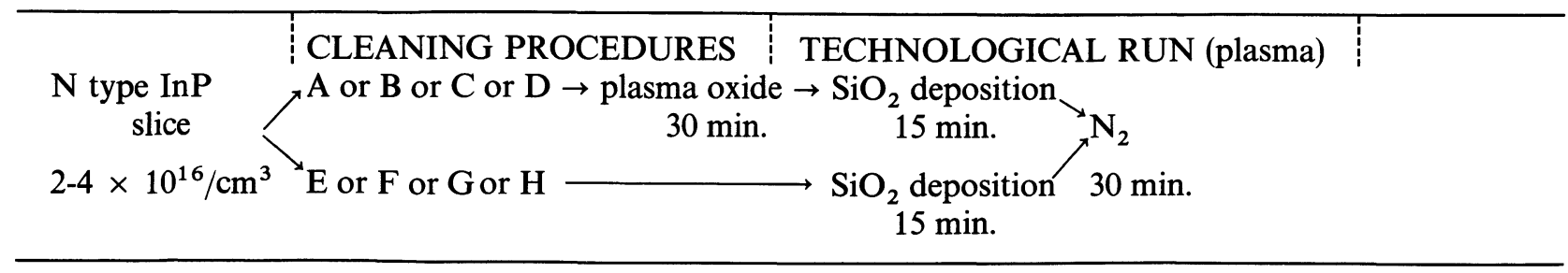


Immediately after this procedure, $\varnothing 375 \mu \mathrm{m} \mathrm{Al}$ dots are evaporated through a metallic mask on the insulator. Then, after a classic etching technique, MIS structures are completed with AuGe ohmic contacts provided on the back side.

\section{Results.}

The dielectric properties of the MIS devices were first checked on each group of samples provided with plasma oxide. The measurements were performed on several MIS, showing the fair homogeneity of the characteristics in each group. The insulator layers exhibit a high resistivity, whatever the cleaning pro-
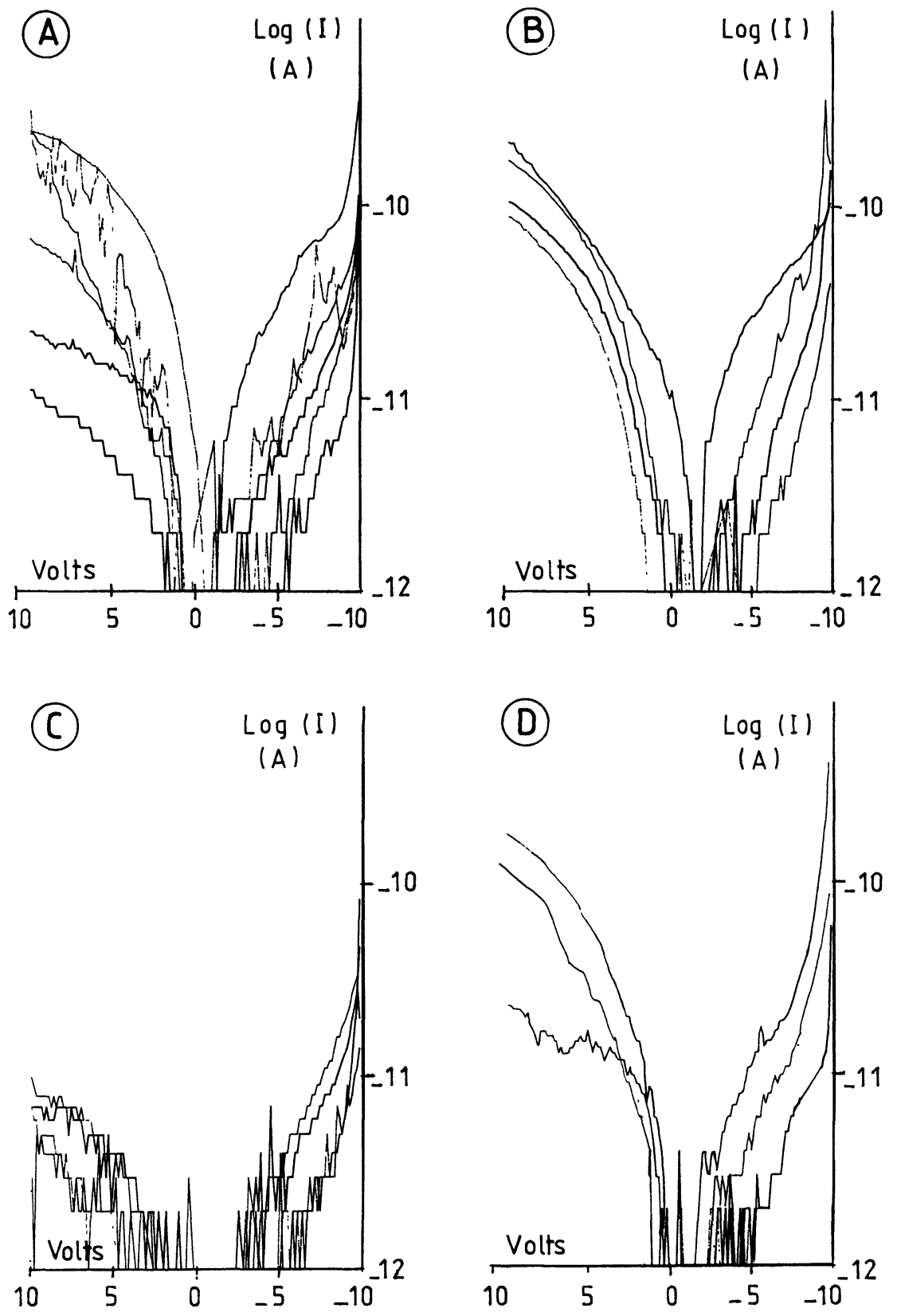

Fig. 2. - Insulator current $v s$. gate bias of MIS devices provided with plasma oxide, according to the cleaning procedures A, $\mathrm{B} ; \mathrm{C}$ or $\mathrm{D}$ 


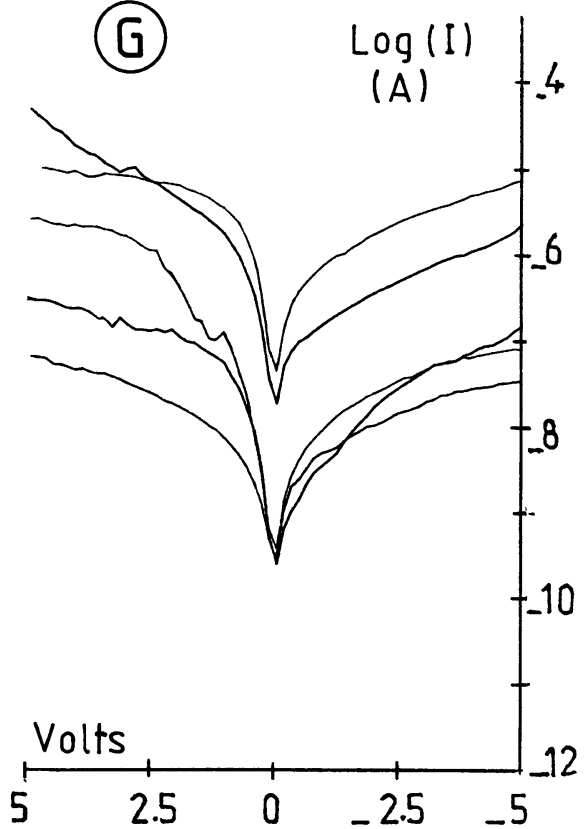

Fig. 3. - Insulator current vs. gate bias of devices without plasma oxide. Only curves related to cleaning procedure $G$ are presented; the other procedures $\mathrm{E}, \mathrm{F}$ and $\mathrm{H}$ give similar results.

improvement to the dielectric property of the system, and its characteristics are highly dependent on the cleaning procedure, the pre-etch procedure $\mathrm{C}$ being here the most convenient one.

- The second way is to consider the $\mathrm{SiO}_{2}$ deposited on the plasma oxide of good quality. In that case, just a slight modification is brought by the plasma oxide to the overall dielectric characteristic of the system, the better native oxide dealing with the cleaning procedure $\mathrm{C}$. To account for the somewhat leaky behaviour of the $\mathrm{SiO}_{2}$ in absence of plasma oxide, we must assume that the properties of the $\mathrm{SiO}_{2}$ layer directly deposited on the InP substrate $(E, F, G$ or $H)$, are modified by some interaction with the InP substrate, whose effect is to degrade the dielectric properties of $\mathrm{SiO}_{2}$. In that hypothesis, the native plasma oxide would play the role of a barrier between the substrate and the deposited insulator.

In order to demonstrate which of these two roles played by the plasma oxide is the most feasible one, a Silicon slice has been processed together with the $\mathrm{E}, \mathrm{F}, \mathrm{G}$ and $\mathrm{H}$ InP samples, and subsequent MOS structures were realized and tested. As a similar thickness of $\mathrm{SiO}_{2}$ is deposited on these substrates, the current across $\mathrm{SiO}_{2} v$ s. gate bias can be directly compared to the I-V curves of the InP structures.

As a result, the dielectric rigidity of the $\mathrm{SiO}_{2}$ layer comes out identical, whatever can be the nature of the substrate - Si or InP. Therefore, the first analysis proposed is the right one. This involves that the growth of a plasma oxide layer is necessary to get a good insulated gate in these experimental conditions.
If we examine now the interface properties of the InP samples, only significant results will be observed when the plasma oxide has been included in the process (samples A, B, C and D). The surface state densities $N_{\mathrm{ss}}$ present at the plasma oxide/InP interface is around $10^{12} \mathrm{~cm}^{-2} \mathrm{eV}^{-1}$ on samples A, B or C, with a slight advantage to the pre-etch $\mathrm{B}$ or $\mathrm{C}$ samples. This density is large enough to be determined by the Terman's method. The ideal characteristics of InP have been obtained from the program developed by G. Sarrabayrouse et al. [14]. It is not surprising to register one order or magnitude higher for $N_{\mathrm{ss}}$ in sample D, according to the absence of a serious cleaning procedure on sample D.

Furthermore, when the gate bias is scanned from $+10 \mathrm{~V}$ to $-10 \mathrm{~V}$ and back to $+10 \mathrm{~V}$, the hysteresis observed, whose magnitude is between 2 and $3 \mathrm{~V}$ at flat band conditions when the rate of measurement is $30 \mathrm{mV} / \mathrm{s}$, is consistent with a carrier exchange between slow states and semiconductor.

To verify that these slow states are mainly located at the plasma oxide $/ \mathrm{SiO}_{2}$ interface, a process has been developed, similar to process $\mathrm{C}$, with a slight difference : after the plasma oxide growth, during which $\mathrm{N}_{2} \mathrm{O}$ was present in the reaction chamber, we allow the $\mathrm{SiH}_{4}$ to enter the chamber gradually from 0 to its nominal flow rate, linearly with time during $5 \mathrm{~min}$. Then, the $\mathrm{SiO}_{2}$ deposition is forwarded as in the normal process. In that way, we expect to get a gradual transition from the $\mathrm{InPO}_{4}$ layer to $\mathrm{SiO}_{2}$ by monitoring the composition of the silicon oxide layer. The effect on the $\mathrm{C}-\mathrm{V}$ characteristics shown in figure 4 is a huge widening of the hysteresis, demonstrating the modification at this interface (no flat band shift). It is interesting to note that no effect on the dielectric properties of the corresponding structures has been observed, confirming the preceding conclusion on the role played by the plasma oxide.

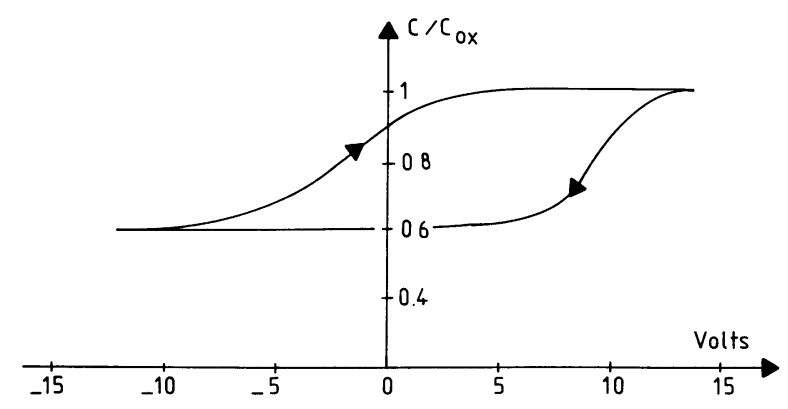

Fig. 4. - $\mathrm{C}-\mathrm{V}$ hysteresis of a structure presenting a gradual transition between plasma oxide and $\mathrm{SiO}_{2}$.

\section{Conclusion. Improvement of the process.}

If the plasma oxide has been shown to tighten the dielectric properties of a MIS on InP when the deposited oxide was not as good as expected, the fast and slow states present still too high densities in our 
experiments to consider this technique as necessary to improve the device quality. In fact, the device acts as a « MNOS » structure, and we must not be surprised by the behaviour observed experimentally.

However, before claiming a minimization, or even an elimination of the native plasma oxide, the improvement of the quality of the deposited insulator is the first necessary step to overcome; therefore, work is still to be done to find an optimization of the process which includes plasma oxide. The annealing procedure will bring definitely an improvement to the MIS characteristics provided that conditions be well settled. As an example, the influence of annealing on our samples in $80 \% \mathrm{~N}_{2}$ and $20 \% \mathrm{H}_{2}$ is shown in figure 5 , and we see that the temperature must be chosen as a compromise between the hysteresis in the C-V characteristics and the densities of interface states. This conclusion is similar to that obtained by $\mathbf{M}$. Matsui et al. [12] on InP MISFETs containing a native oxide film interlayed between an $\mathrm{Al}_{2} \mathrm{O}_{3}$ anodic oxide and InP.

Aside new different annealing methods which can be proposed [15], other factor to be studied is the temperature of the PECVD process itself; a temperature of $300^{\circ} \mathrm{C}$ to $350^{\circ} \mathrm{C}$ certainly improve the rigidity of $\mathrm{SiO}_{2}$ as well as the interface properties.

Finally, the composition of the reactant gases will be monitored to find out the optimized composition of the $\mathrm{SiO}_{2}$.

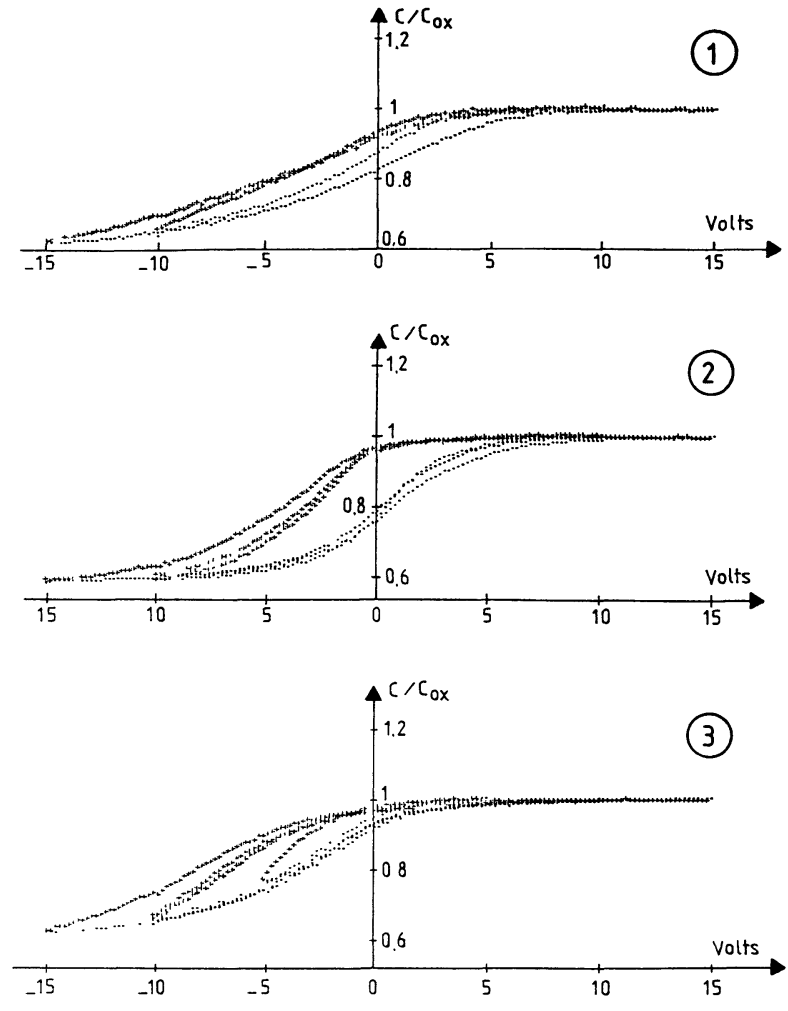

Fig. 5. - Effect of annealing temperature : $340^{\circ} \mathrm{C}$ (1), $300^{\circ} \mathrm{C}$ (2), $220^{\circ} \mathrm{C}$ (3) on the $\mathrm{C}-\mathrm{V}$ characteristics of devices provided with plasma oxide; the optimum effect is obtained at $300^{\circ} \mathrm{C}$.

\section{References}

[1] Simonne, J. J., INFOS 83 Conf. Eindhoven (P.B.) (1983) State of the art in InP MIS Technology.

[2] Cameron, D. C., Irving, L. D., Jones, G. R. and WoOdWARD, J., Proc. INFOS 81 (1981) 281.

[3] MeIners, L. G., J. Vac. Sci. Techn. 21 (1982) 655.

[4] Wager, J. F. and Wilmsen, C. W., J. Appl. Phys. 53 (1982) 5789.

[5] Meiners, L. G. and Lile, D. L., IEDM Tech. Dig. 108 (1981)

[6] Lile, D. L. and Taylor, M. J., J. Appl. Phys. 54 (1983) 260.

[7] Lile, D. L., Collins, D. A., Meiners, L. G. and TAYLOR, M. J., Inst. Phys. Conf. Ser. $\mathrm{n}^{\circ}$ 56, Chap. 7 (1981) 493.

[8] Guivarc'h, A., Laridon, H., Pelous, G., Hollinger, G. and Pertosa, P., Workshop on Dielectric Systems for the III.V. Compounds, San Diego (1982).
[9] Kern, W., Puotinen, D. A., RCA Rev. 31 (1970) 187. [10] Armand, M., Bui, D. V., Chevrier, J. and Linh, N. T., DAII Contr. no 81-35-138 (1983).

[11] FritzsCHE, D., Electron. Lett. 14 (1978) 51.

[12] Matsui, M., Hirayama, Y., Arai, F. and Sugano, T., to be published in IEEE Electr. Dev. Lett.

[13] Guivarc'h, A., et al., to be published in J. Appl. Phys.

[14] Sarrabayrouse, G., Capilla, C. and Fiore de Mattos, A. C., to be published in this review.

[15] Spicer, W. E., Lindau, I., Eglash, S., Petro, W., Skeath, P. and Su, C. Y., Int. Electr. Dev. Meet. Tech. Dig. 106 (1981). 